\title{
Eye-tracking glasses for improving teacher education: the e-Teach project
}

\author{
Filomena Faiella ${ }^{a}$, Emiliana Mannese ${ }^{\mathrm{b}}$, Giulia Savarese ${ }^{\mathrm{c}}$, Antonina Plutino ${ }^{\mathrm{d}}$, Maria \\ Grazia Lombardi ${ }^{\mathrm{e}}$
}

\author{
${ }^{a}$ University of Salerno, Italy, ffaiella@unisa.it, 0000-0002-8265-0300 \\ ${ }^{b}$ University of Salerno, Italy, emannese@unisa.it,0000-0003-3115-4793 \\ ${ }^{c}$ University of Salerno, Italy, gsavarese@unisa.it,000-0002-0974-6429 \\ ${ }^{d}$ University of Salerno, Italy, aplutino@unisa.it,0000-0002-2442-708X \\ ${ }^{e}$ University of Salerno, Italy, mlombardi@unisa.it,0000-0001-7425-321X
}

\begin{abstract}
This paper is about "Improvement of teaching techniques by eye tracking in technology enhanced classrooms" (eTeach), an innovative project funded by the Erasmus Plus Programme (KA2 - Strategic Partnership in the field of School Education). The project aims to study teachers' eye movements in real teaching situation using eye-tracking glasses and compares the teachers' use of digital technologies between novices and experts teaching the same school subject. The purpose of this study was to provide indicators of skill gaps between novices and experts which can be addressed appropriately with highly targeted teacher education. The first part of the paper reviews recent developments in conceptual frameworks for digital competence and in digital competence descriptors. The second part describes the project status, the methods and its phases. In conclusion, the paper gives a brief overview of initial findings of ongoing research, focusing largely on the Italian experience, and development tasks for the next project phases. The initial findings suggest that teachers valued the benefits of using digital technologies in classrooms and recognized the necessity of professional development. They also provided specific insights for the purpose of developing an online course for teacher education in four languages: English, Turkish, Italian and Lithuanian.
\end{abstract}

Keywords: e-learning, digital technologies, teacher education, eye-tracking glasses, strategic partnership.

\section{Introduction}

An investigation of the concept of competence in the human and social sciences must take into account its complex and multidimensional nature. Lombardi (2014), in a recent paper on professional competence of teachers, examined the scientific definitions of the concept embedded within their theoretical interpretative frameworks. Starting from the contributions of Le Boterf (2008), Vitolo (2008), Di Fabio (2002) and Perrenoud (2002), she defines competence as «a process induced by at least three elements: the situations, the resources, the nature of thought patterns that leads to mobilization of relevant resources in complex situations» (Lombardi, 2014, 66).

The concept of digital competence is just as complex, albeit for different reasons. The basic ideas behind this concept were traceable to a paradigm shift in 2006, when the recommendation on key competences for lifelong learning proposed a definition of digital competence as «the confident and critical use of Information Society Technology (IST) for work, leisure and communication. It is underpinned by basic skills in ICT: the use of computers to retrieve, assess, store, produce, present and exchange information and to communicate and participate in collaborative networks via the Internet» $(2006 / 962 / \mathrm{EC}, 15)$.

Digital competence has been synthesized in the European Digital Competence Framework (Redecker, 2017), published in 2017 by the European Commission's Joint Research Centre (JRC), on behalf of the Directorate-General for Education, Youth, Sport and Culture (DG EAC).

This provoked a broad debate among academics and practitioners and the development of initiatives, models, tools and instruments based on the DigCompEdu conceptual model (Bocconi, Panesi, 2018; Limone, Parmigiani, 2017; Ravotto, 2017; Carretero et al., 2017; Menichetti, 2017).

The European framework (DigCompEdu) identifies and describes 22 descriptors of educators' digital competence, which are divided into six areas of professional activities: professional engagement, digital resources, teaching and learning, assessment, empowering learners, facilitating learners' digital competence. 


\section{Eye tracking glasses for improving teacher education: the e-Teach project \\ Faiella, Mannese, Savarese, Plutino, Lombardi}

The e-Teach project, which is the topic of this paper, focuses its attention primarily on those areas that are related to educators' pedagogic competences defined by Areas 2-5 of the European framework (DigCompEdu). The purposes of the project are to provide indicators of skill gaps between novices and experts and to address appropriately with highly targeted teacher education.

\section{The e-Teach project}

A brief overview of the eye-tracking research literature demonstrates the ability of eye-tracking methodology to provide reliable quantitative data as an objective assessment tool (Wang et al., 2019; Antonenko, 2019; Duchowski, 2007) and shows that, during the past two decades, eye-tracking technology has increased its popularity among practitioners and researchers from a wide variety of research fields such as usability analysis, sports sciences, surgical training, cognitive psychology, reading research, psycholinguistic, neurophysiology, software engineering and others. In educational research, eye-tracking technology was used to investigate learning processes in educational settings (e.g. pedagogic supports, multimedia learning, online spoken language comprehension and e-learning) and to study cognitive processes linked to learning and performances (e.g. language acquisition, reading, memory, mindsets and motivation and language processing of children with developmental disorders) (Flynn et al., 2019; Alemdag, Cagiltay, 2018; Yang et al., 2018; Was et al., 2017).

Wearable eye-tracking glasses are a technology to collect, register and record eye movement data, useful for situations where the user needs to be fully mobile allowing for maximum mobility and flexibility and without the typical constraint of an eye tracker in a fixed position.

The e-Teach project used eye-tracking glasses for studying teachers' eye movements in real teaching situation and compared the teachers' use of digital technologies between novices and experts teaching the same school subject. In the project, "novice" means a teacher who is new to teaching with digital technologies and "expert" means teachers using digital technologies for a long time with their students, regardless of the years of teaching experience they have. The aim is to see how experienced teachers' lessons differ from those of novices. The researchers in each participating university analyzed the classroom observation which was digitally recorded, eye-tracking data and interviews to infer differences and similarities between novices and experts.

The results will provide valuable indicators of skill gaps that can be addressed appropriately with targeted training. The most important thing at the end of the project execution phase is to develop an online course for teacher education in four languages: English, Turkish, Italian and Lithuanian.

\section{Research methodology}

"Improvement of teaching techniques by eye tracking in technology enhanced classrooms" (e-Teach) is an innovative project running from September 2017 funded under the European Commission Erasmus Plus programme for Strategic Partnerships. The project is coordinated by Middle East Technical University of Ankara (Turkey), and the project partners are as follows: Damasistem Yazilim, National Ministry of Education, Cenk Yakin Ortaokulu, Ogretmen Akademisi Vakfi from Turkey, University of Salerno and Istituto Comprensivo "Gragnano 3 Staglie Parco Imperiale" from Italy and Vilnius University and Druskininku Saules pagrindine mokykla from Lithuania.

The project aims to provide an accurate assessment of skill gaps between experts and novices for identifying training requirements needed to develop teacher-specific digital competences. The assessment of skill gaps relied on the collection, analysis and triangulation of three sets of data: (A) the eye-tracking data, (B) the classroom observations and (C) the interviews. In this project, the triangulation refers to the use of a variety of data collection sources to seeking convergences and corroboration of results (Henning et al., 2004).

The researchers of each participating university (Middle East Technical University of Ankara, University of Salerno and Vilnius University) have analyzed the data collected in the school of own country (Cenk Yakin Ortaokulu, Istituto Comprensivo "Gragnano 3 Staglie Parco Imperiale” and Druskininku Saules pagrindine mokykla).

In this paragraph, we explain the methodology adopted for data collection and analysis, focusing largely on the University of Salerno research team experience. Each member of the University of Salerno team has different fields of study and works together in an interdisciplinary manner to generate a more comprehensive appreciation of the project issues.

\subsection{Data collection}

Before we go ahead with discussing the analysis of data, understanding the data collection is crucial.

The data collection proceeded in four stages, where the first one (the pilot stage) is to test the procedures and reduce novelty effect, a threat to external validity that occurs when individuals participating in a research study perform differently than they would in a neutral condition. The other stages consist of the recorded lessons, interviews and recorded lessons post interviews.

The data collection involved classes in lower secondary school. Each school has chosen six classroom teachers, an expert novice pair for each school subject involved in the project. The recording took place during a regular class period 
selected to minimize interference with the regular teaching plan. The recording system obtained images from the eyetracking glasses, as teachers moved freely about their classroom activities, and two stationary cameras positioned at different angles to provide additional classroom footages. The researchers were not present during class time. On the Italian level, however, the school had to involve the last class of primary school for the lessons of Science because in Italy the same teacher teaches both Mathematics and Science in the lower secondary school.

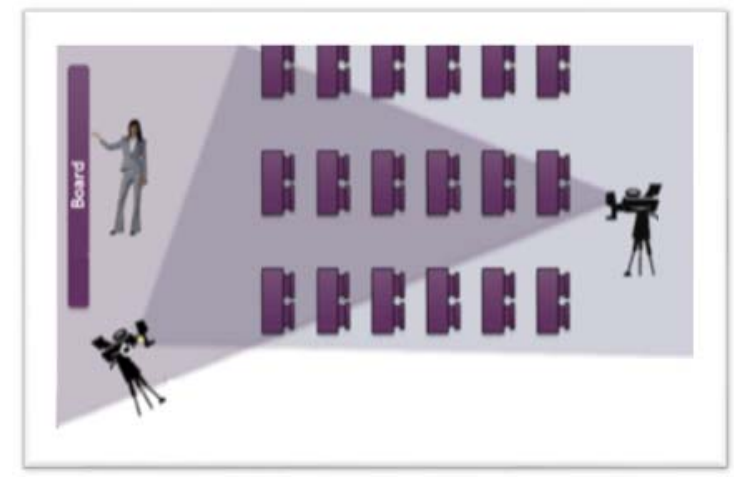

Fig. 1 The recording system.

Twenty-four lessons were recorded in every participating school, beyond the pilot phase records. The expert novice pair therefore taught similar lessons in the same school subject (literacy, mathematics and science). The three novices finally recorded one last lesson after watching the recordings both own lessons and those of the expert colleague.

Therefore, getting back to the classroom observation in Italy, the number of lessons and the duration of the recordings are summarized in Table 1.

Table 1 The classroom observation at the University of Salerno.

\begin{tabular}{lll}
\hline Recordings & Number & Hours \\
\hline Pilot & 9 & 5 \\
Recorded lessons & 24 & 14 \\
Post-interviews & 3 & $1: 5$ \\
\hline
\end{tabular}

\subsection{Eye-tracking analysis}

The e-Teach project used Tobii Pro Glasses to register and record the eye movements, and Tobii Pro Lab software was used to analyze the eye-tracking data and to know exactly where the teacher looked and for how long. Every research team has analyzed the eye-tracking data of the 27 lessons using the visualization technique of heat maps to get an idea about which elements attracted the teacher's attention and which items were not looked at all.

Heat map is a static visualization, which displays the viewing behaviour of the teachers and shows the spots where teachers have focused on more frequently and where not, through a scheme of different colours to depict either the amount or the duration of fixations of different parts. Warm colours (red and yellow) indicate areas, which were looked at longer.

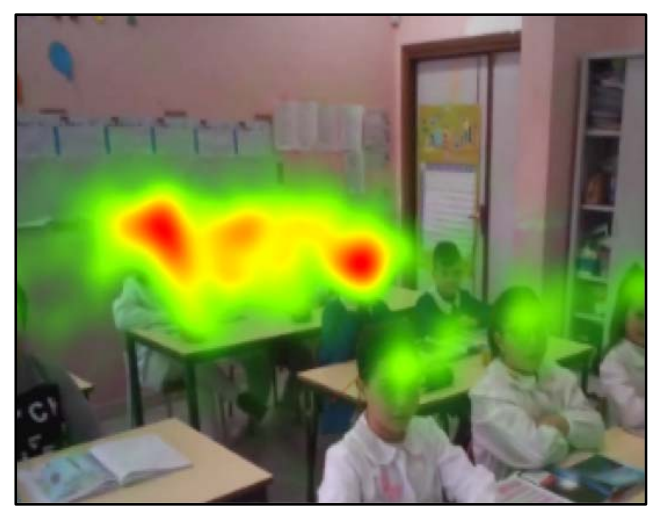

Fig. 2 The heat map. 


\subsection{Analysis of lessons}

The recording system achieves three classroom footages: one from the eye-tracking glasses and two from the stationary cameras positioned at two different angles of the classrooms. The three footages were combined side by side for the analysis of lessons.

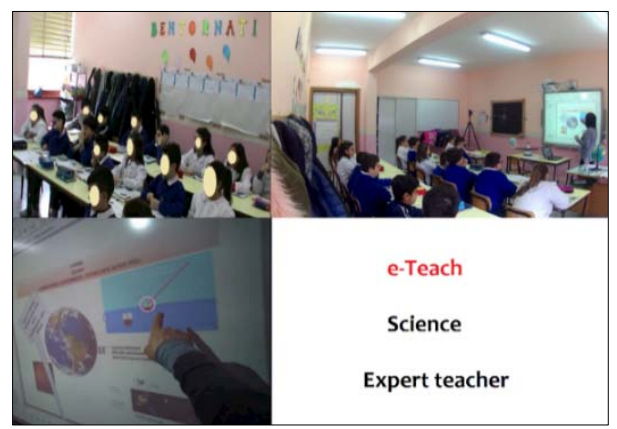

Fig. 3 The footages combined side by side.

Fig. 3 shows the three video streams simultaneously by side by side: the footage in low left allows to see exactly where the teacher looks and the remaining shows the perspective of the stationary cameras and allows to see what the teacher does and what the pupils do.

The lesson footages combined side by side were reviewed repeatedly for two different levels of analysis. The first was more approximate to make notes about them in the order of events and deduce the aspects to be discussed with the teachers during the interviews. This meant writing down times in the classroom observation and adding the questions to ask the teachers.

The second most is described here. The instrument for collecting evidence from the classroom observation is a lesson sequences grid (Fig. 4). Every lesson sequences grid indicates the date of the observation, the specificity of the teacher (novice/expert), the school subject and the topic of the lesson. Then, we used it to collect the evidence on teachers' behaviours and students' interactions in a high-inference qualitative format. The lesson sequences grid implemented the lesson as a sequence of lesson segments or activities, a segment being a block of time with a particular intention. The grid presented in Figure 4 shows the activities written systematically together with the relative elements, such as what the teacher does, what the pupils do and the digital and non-digital technology with which they are carrying out the activity.

\begin{tabular}{|c|c|c|c|c|}
\hline \multicolumn{5}{|c|}{ Lesson sequences } \\
\hline \multicolumn{5}{|c|}{$\begin{array}{l}\text { Subject: Sciences } \\
\text { Topic: Earth } \\
\text { Time: } 11: 45 \text { a.m. - } 20 \text { March, } 2018 \\
\text { Teacher: Novice } \\
\text { Class: } 5 \text { B }\end{array}$} \\
\hline & activity & teacher & pupils & technology \\
\hline Until 3:14 & opening & talk & listen & . \\
\hline $3: 48$ & instruction & $\begin{array}{l}\text { she says they can } \\
\text { follow from either } \\
\text { the book or the } \\
\text { screen }\end{array}$ & nod & - \\
\hline $3: 55$ & explanation & $\begin{array}{l}\text { about how the } \\
\text { earth is made }\end{array}$ & listen & globe \\
\hline 4:16 & explanation & $\begin{array}{l}\text { Read from } \\
\text { the e book }\end{array}$ & $\begin{array}{c}\text { some follow from } \\
\text { the book, the } \\
\text { others listen }\end{array}$ & IWB with e-book \\
\hline $4: 40$ & explanation & $\begin{array}{l}\text { Explain what } \\
\text { she read }\end{array}$ & $\begin{array}{l}\text { someone nods, } \\
\text { everyone listens }\end{array}$ & globe \\
\hline $5: 00$ & explanation & $\begin{array}{l}\text { Show an image to } \\
\text { clarify the concept }\end{array}$ & Say yes & IWB with e-book \\
\hline$s: 10$ & explanation & $\begin{array}{l}\text { Read from the e- } \\
\text { book }\end{array}$ & $\begin{array}{l}\text { one follow from } \\
\text { the book, the } \\
\text { others listen }\end{array}$ & IWB with e-book \\
\hline $5: 14$ & explanation & $\begin{array}{l}\text { Explain what } \\
\text { she read and } \\
\text { anticipates what } \\
\text { she will explain } \\
\text { later }\end{array}$ & listen & . \\
\hline
\end{tabular}

Fig. $4 \mathrm{~A}$ lesson sequences grid. 
The lesson segments are organized under two broad categories: segments addressing content and segments involving management. Lesson segments addressing content are activities regarding academic content such as opening (a preview of the lesson), instruction (presentation of the task), closure (check what students have learned), explanation, class work, assessment, summarizing, homework correction, etc. Activities related to managing the technology, timing, physical environment, unexpected events, procedures for participating in class discussion and homework assignment are all considered segments involving management.

\subsection{Interviews}

After recording the 24 lessons and combining the footages side by side, we made provisional analysis of them and selected the most important issues and events. We then created effective research questions to stimulate discussion in the interview to learn more on the lessons and where and why teacher's eye movements have stopped on. In such a way, we developed a personalized semi-structured interview for each teacher and conducted individual interviews after the scheduled period of recorded lessons.

The semi-structured interviews have provided core elements of the lessons being studied. The interview process requires that each teacher can watch videos of their own lessons and that also the novices watch lessons of experienced teachers to reflect on the differences detected. We maintained a special kind of non-judgemental attitude to help teachers understand "what" they are doing and "why" they are doing it, accepting every aspect of the teachers' experience as part of their identity.

Interviews were recorded and transcribed.

As part of the study, every teacher completed a survey on a number of topics that include the following: (1) the relationship with digital technologies, (2) attitudes towards the use of computers, (3) digital tools used routinely and (4) the aims of using digital technologies in education.

Table 2 Answers to the survey questions.

\begin{tabular}{|c|c|c|c|c|c|c|}
\hline & $\begin{array}{l}\text { Expert } \\
\text { Maths }\end{array}$ & $\begin{array}{l}\text { Novice } \\
\text { Maths }\end{array}$ & $\begin{array}{l}\text { Expert } \\
\text { Italian }\end{array}$ & $\begin{array}{l}\text { Novice } \\
\text { Italian }\end{array}$ & $\begin{array}{l}\text { Expert } \\
\text { Science }\end{array}$ & $\begin{array}{l}\text { Novice } \\
\text { Science }\end{array}$ \\
\hline $\begin{array}{l}\text { relationship with } \\
\text { digital technologies }\end{array}$ & Good & Good & Very good & Satisfactory & Excellent & Satisfactory \\
\hline $\begin{array}{l}\text { attitudes towards } \\
\text { the use of } \\
\text { computers }\end{array}$ & $\begin{array}{l}\text { Perceived } \\
\text { usefulness }\end{array}$ & $\begin{array}{l}\text { Perceived } \\
\text { usefulness }\end{array}$ & $\begin{array}{l}\text { Curious and } \\
\text { interested }\end{array}$ & Favourable & Positive & Positive \\
\hline $\begin{array}{l}\text { digital technology } \\
\text { and tools used } \\
\text { routinely }\end{array}$ & $\begin{array}{l}\text { PC - IWB - } \\
\text { Geogebra - } \\
\text { Educational } \\
\text { websites }\end{array}$ & IWB - PC & IWB - PC & $\begin{array}{l}\text { IWB - Google } \\
\text { Maps - } \\
\text { Digilander }\end{array}$ & $\begin{array}{l}\text { IWB - PC - } \\
\text { Tablet }\end{array}$ & $\begin{array}{c}\text { IWB - PC - } \\
\text { Smartphone - } \\
\text { Educational games - } \\
\text { PowerPoint - Digital } \\
\text { books - Platforms }\end{array}$ \\
\hline $\begin{array}{l}\text { aims of using } \\
\text { digital technologies } \\
\text { in education }\end{array}$ & $\begin{array}{c}\text { Explain - assess - } \\
\text { deepen - show }\end{array}$ & $\begin{array}{l}\text { Explain - } \\
\text { Exercise }\end{array}$ & $\begin{array}{l}\text { Open - } \\
\text { explain }\end{array}$ & $\begin{array}{l}\text { Explain - } \\
\text { Assess }\end{array}$ & $\begin{array}{l}\text { Interact - } \\
\text { assess }\end{array}$ & $\begin{array}{l}\text { Explain - } \\
\text { assess }\end{array}$ \\
\hline
\end{tabular}

Data analysis is currently under way, and the first results from the interview with the Italian teachers show that (1) every teacher interviewed demonstrated interest in watching the recordings of own lessons; (2) most teachers appreciated so much the data collection method, in which they were not afraid to be judged; (3) the prevalent feeling was that the data collection method helped improve concentration in the classroom and (4) all the teachers were particularly interested in the use of digital technologies.

\section{Initial findings}

The initial findings presented here represent that the data are collected in Italy within the scope of the project. We provide an overview of the participant teachers and school first, then some qualitative considerations among the variables under analysis. For the ease of presentation, these considerations will be linked to the educators' pedagogic competences used by the European Digital Competence Framework (DigCompEdu).

The school studied by the University of Salerno team is the Istituto Comprensivo "Gragnano 3 Staglie Parco Imperiale". The school has an interactive whiteboard in every classroom and a number of teachers actively using it in their classes. The school leadership team considers the effective and responsible uses of digital technologies as a boost to encourage innovation in education. 


\section{Eye tracking glasses for improving teacher education: the e-Teach project \\ Faiella, Mannese, Savarese, Plutino, Lombardi}

The most important features of the participant teachers are provided in Table 3, and they are related to the years of teaching experience, the problems they had with eye-tracking glasses and the differences between usual way of teaching and the recorded lessons. We remember that two teachers (Science teachers) wear glasses under the Tobii glasses. Moreover, the classroom teachers at the school received professional development in the previous years to successfully integrate digital technologies into daily learning experiences for their students. Nevertheless, they are open to new ideas, knowing that there are many things they could learn yet.

Table 3 The most important features of the teachers.

\begin{tabular}{lcll}
\hline Teacher & $\begin{array}{c}\text { Years of teaching } \\
\text { experience }\end{array}$ & Eye-tracking glasses & Usual way of teaching \\
\hline $\begin{array}{l}\text { Expert } \\
\text { Maths }\end{array}$ & 16 & bother when wear for too long & no IWB in every lesson \\
\hline $\begin{array}{l}\text { Novice } \\
\text { Maths }\end{array}$ & 10 & no problem & more interaction \\
\hline $\begin{array}{l}\text { Expert } \\
\text { Science }\end{array}$ & 32 & temptation to touch & more interaction \\
\hline $\begin{array}{l}\text { Novice } \\
\text { Science }\end{array}$ & 32 & temptation to touch & no difference \\
\hline $\begin{array}{l}\text { Expert } \\
\text { Italian }\end{array}$ & 8 & $\begin{array}{l}\text { annoyed by the pocket-sized } \\
\text { unit }\end{array}$ & no difference \\
\hline $\begin{array}{l}\text { Novice } \\
\text { Italian }\end{array}$ & 4 & no problem & using more software \\
\hline
\end{tabular}

\subsection{Digital Resources}

According to the European Digital Competence Framework, teachers should be able to effectively identify software and resources that best fit their learning objectives, students and teaching style. Here, we report the number and kind of software and digital resources, both used in the recorded lessons, and that they say they know best and try to understand what teachers consider when they select software and digital resources to support learning.

The Mathematics teachers use GeoGebra, a free software that offers geometry, algebra and calculus features for teaching and learning mathematics. The expert Mathematics teacher also shares digital learning materials produced in the classroom with students on a platform (Fidenia) that seeks to make effective links between home and school in supporting students' learning and development. As they stated in the interview, they often select online resources and software (including apps and games). A novice Mathematics teacher also stated in the interview that she uses Padlet and Excel with her students.

The Science teachers use the digital textbook, interactive exercises and videos and enhance their lessons with other non-digital learning tools, such as human body model, tellurium and globe.

The Italian expert teacher uses only the interactive whiteboard specially to create concept maps and schemes that help students remember and understand better. The Italian novice teacher, unlike the expert, uses different software and digital tools, such as PowerPoint, conceptual maps, interactive exercises and schemes. Both said that they also use other digital resources available through the Internet and Google Maps to teach geography.

The first important difference we observe is the use of non-digital learning tools by the teachers of the primary school. As emerged from the interviews, they feel the need to develop a clear understanding of concepts and to aid students to make connection from tangible concrete object to its abstraction. They then choose different non-digital tools, which they believe might be suited for this purpose. Another interesting difference is that between the Italian teachers. The novice teacher uses many digital tools. She is the youngest of the teachers involved in the project and just finished pre-service teacher education. We can think it is the effect of the formal training in instructional technology courses that she has attended.

\subsection{Teaching and Learning}

The fundamental competence in this area refers to a teacher who is able to be a guide for learners in his/her progressively more autonomous learning endeavours.

As the study showed, the expert Mathematics teacher uses the platform Fidenia for sharing digital learning materials with students and makes effective links between home and school in supporting students' learning and development. 


\section{Eye tracking glasses for improving teacher education: the e-Teach project \\ Faiella, Mannese, Savarese, Plutino, Lombardi}

She also helps the students develop skills, explaining the mistakes made by learners in the exercises. The novice Mathematics teacher stimulates students to conceptualize the theory from the exercises they perform together.

The Italian expert teacher builds conceptual maps in the classroom with her students to teach students organize and represent knowledge of a subject. Another important contribution related to this area concerns the Italian novice teacher, who encourages learners to use digital technologies for information retrieval on the subject matters.

The Science teacher feels the need to develop a clear understanding of concepts and to aid students to make connection from tangible concrete object to its abstraction using different non-digital tools, videos, images and so on. The expert Science teacher also uses "special effects" to foster understanding (e.g. she used a balloon full of paper balls that she blew up with a pin to explain the Big Bang theory), and the novice Science teacher simulates the movement of the Earth and invites students to remember when they have simulated the movements of the Earth around the Sun.

\subsection{Assessment}

The area 4 of the European Framework for the Digital Competence of Educators concerns digital assessment. According to the framework, teacher should be able to enhance existing assessment strategies or facilitate innovative assessment approaches using digital technologies. Unfortunately, we have no evidence concerning the ability of the teachers involved to appropriately use digital technologies to enhance assessment strategies. Even though the answers to the question regarding the aims of using digital technologies in education in Table 2 indicated that the teachers use digital strategies to enhance assessment, the interviews and analysis of lessons show that they usually use interactive exercises (e.g. multiple choice questions and cloze tests) to engage students and verify whether the students have understood the explanation. The thing missing is ability to use digital technologies for formal evaluation of student learning and to analyze and interpret digital evidence on learner activity, performance and progress, to inform teaching and learning.

\subsection{Empowering learners}

According to the European Digital Competence Framework, teacher should be able also to involve actively learners in the learning process, including those with special needs.

Concerning this area, we have interesting data.

The expert Italian teacher usually encourages learners to use digital technologies creatively to foster learners' deep thinking and creative expression and increase their active involvement in the subject matter. We had the opportunity to witness this: in her class, a student presented a PowerPoint on yellow genre; she also told us in the interview that a student created a digital comic about Manzoni. The novice Italian teacher uses the interactive exercises (Digilander) to engage students and verify if they have understood the explanation.

The Mathematics teacher invites students to the board to verify if the they have understood the explanation.

The expert Science teacher uses cloze tests to engage students and verify their knowledge of key terms in the subject. In the interview, she also said she usually uses brainstorming and debate and often invites students to make posters and research about main themes of the subject matter. The novice Science teacher uses an app (Mondadori) which allows students to learn by playing, searches learning materials in the Internet to answer every question and satisfy curiosities of the students, invites students on a rotating basis to complete cloze tests and verify if they have understood the explanation and uses conceptual maps that the students have to complete.

\section{Conclusions and future perspectives}

The purpose of this study was to describe e-Teach project, which aims to provide indicators of skill gaps between novices and experts which can be addressed appropriately with highly targeted teacher education.

We started to describe recent developments in conceptual frameworks for digital competence and in digital competence descriptors. Then, we described the project status, the methods and its phases. We gave a brief overview of initial findings of ongoing research in the last paragraph.

The initial findings presented are some qualitative considerations among the variables under analysis. The data collected in Italy within the scope of the project revealed the information about the importance of the development of teacher' digital competence. The European Digital Competence Framework (DigCompEdu) emphasizes the need to fostering teacher' digital competence and our study has shown how much is needed.

The teachers are able to select digital resources to suit the learning objective and existing competence level of the learners, but all have shown a willingness to learn how to create new digital educational resources. A second point on which targeted training should focus should be the use of digital technologies to foster collaborative knowledge building. Finally, we need to rethink how to use digital technologies to enhance assessment strategies.

The next steps will be devoted to derive indicators which, on one hand, relate to the skill gaps between novices and experts and, on the other hand, are defined rigorously in terms of outcomes of teacher education.

The triangulation is the first next step of the project; we have to seek convergences and corroboration of results through the comparison among the eye-tracking data, the classroom observations and the interviews. 
Then, we have to compare the results obtained by the three universities to identifying practical implications in developing an online course for teacher education on digital technologies in four languages: English, Turkish, Italian and Lithuanian.

\section{Acknowledgment}

This study was carried out within the framework of the European funded project e-Teach (Erasmus Plus Programme, KA2, 2017-20, EC Project Number: 2017-1-TR01-KA201-046748). The paper is conceived by all the authors whose contribution is as follows: Filomena Faiella is the principal investigator of the University of Salerno team and wrote Abstract, Sections 2, 2.1, 2.2, 3, 3.1, 3.2, 3.3, 3.4 and Conclusions and future perspectives. Emiliana Mannese wrote Section 2.3. Giulia Savarese wrote Section 2.4. Antonina Plutino wrote Section 1. Maria Grazia Lombardi wrote the Introduction. We would like to thank Ozgur Esen, phd for developing and sharing the picture which is being used as Fig. 1. We would also like to thank the pupils, teachers, leadership team and headmaster of the school which participated in the project.

\section{References}

Alemdag E., Cagiltay K. (2018). A systematic review of eye tracking research on multimedia learning. Computers \& Education, 125, 413-428.

Antonenko P.D. (2019). Educational Neuroscience: Exploring Cognitive Processes that Underlie Learning. In: T. Parsons, L. Lin, D. Cockerham (Eds.). Mind, Brain and Technology. Educational Communications and Technology: Issues and Innovations (27-48). Cham: Springer.

Bocconi S., Panesi S. (2018). Teachers' professional learning and competence in the digital era. The DigCompEdu framework. In M. Ranieri, L. Menichetti, M. K. Borges (eds.), Teacher Education \& Training on ICT between Europe and Latin America (39-48). Roma: Aracne editrice.

Carretero S., Vuorikari R., Punie Y. (2017). The Digital Competence Framework for Citizens. Luxembourg: Publications Office of the European Union.

Di Fabio A. (2002). Bilancio di competenze e orientamento formativo, Firenze: Giunti O.S.

Duchowski A.T. (2007). Eye Tracking Methodology: Theory and Practice. London: Springer.

European Union (2008). Recommendation the European Parliament and the Council of 18 December 2006 on Key Competences for Lifelong Learning. Official Journal of the European Union (2006/962/EC), L394/10-18.

Flynn R. M., Wong K. M., Neuman S. B., Kaefer T. (2019). Children's attention to screen-based pedagogical supports: an eye-tracking study with low-income preschool children in the United States. Journal of Children and Media, 13(2), 180-200.

Henning E., Van Rensburg W., Smit B. (2004). Finding your way in qualitative research. Pretoria: Van Schaik.

Le Boterf G. (2008). Costruire le competenze individuali e collettive. Napoli: Alfredo Guida Editore.

Limone P., Parmigiani D. (2017). Modelli pedagogici e pratiche didattiche per la formazione iniziale e in servizio degli insegnanti. Bari: Progedit.

Lombardi M.G. (2014). Competenze nella responsabilità. L'educativo scolastico. Pisa: ETS.

Menichetti L. (2017). La competenza digitale: dalla definizione a un framework per la scuola. Media Education, 8(2), 175-195.

Perrenaoud P. (2002). Dieci nuove competenze per insegnare. Roma: Anicia.

Ravotto P. (2017). DigComp versione 2.1 e DigCompEdu. Bricks, 7(3), 113-127.

Redecker C. (2017). European Framework for the Digital Competence of Educators: DigCompEdu. Punie, Y. (ed.). EUR 28775 EN. Luxembourg: Publications Office of the European Union.

Vitolo M. (2008). Guy Le Boterf. Costruire le competenze individuali e collettive. Napoli: Guida.

Wang J., Antonenko P., Celepkolu M., Jimenez Y., Fieldman E., Fieldman A. (2019). Exploring Relationships Between Eye Tracking and Traditional Usability Testing Data. Journal of Human-Computer Interaction, 35(6), 483-494.

Was C., Sansosti F., Morris B. (2017). Eye-Tracking Technology Applications in Educational Research. Hershey: IGIGlobal.

Yang F.-Y., Tsai M.-J., Chiou G.-L., Lee S. W.-Y., Chang C.-C., Chen L.-L. (2018). Instructional Suggestions Supporting Science Learning in Digital Environments Based on a Review of Eye Tracking Studies. Journal of Educational Technology \& Society, 21(2), 28-45. 